Atmos. Chem. Phys., 6, 2005-2015, 2006

www.atmos-chem-phys.net/6/2005/2006/

(C) Author(s) 2006. This work is licensed

under a Creative Commons License.

\title{
Overview of the European project FUMAPEX
}

\author{
A. Baklanov \\ Danish Meteorological Institute, DMI, Lyngbyvej 100, Copenhagen, DK-2100, Denmark
}

\begin{abstract}
The quality of the urban air pollution forecast critically depends on the mapping of emissions, the urban air pollution models, and the meteorological data. The quality of the meteorological data should be largely enhanced by using downscaled data from advanced numerical weather prediction models. These different topics, as well as the application of population exposure models, have traditionally been treated in distinct scientific communities whose expertise needs to be combined to enhance the possibilities of forecasting air pollution episodes in European cities. For this purpose the EU project "Integrated Systems for Forecasting Urban Meteorology, Air Pollution and Population Exposure" (FUMAPEX) (http://fumapex.dmi.dk), involving 22 organizations from 10 European countries, was initiated. The main objectives of the project are the improvement of meteorological forecasts for urban areas, the connection of numerical weather prediction models to urban air pollution and population exposure models, the building of improved Urban Air Quality Information and Forecasting Systems, and their application in cities in various European climates. This paper overviews the project items and first two-years results, it is an introduction to the whole $\mathrm{ACP}$ issue.
\end{abstract}

\section{Introduction}

The last decades have seen a general improvement of the air quality within many of the European urban areas. The use of cleaner fuel and improved technologies for private heating, the introduction of catalytic devices in new generation cars, and the contextual decommissioning of industrial activities have all contributed to the lowering of urban air concentrations of primary pollutants $\left(\mathrm{SO}_{2}, \mathrm{NO}_{\mathrm{x}}, \mathrm{PM}\right.$, etc.) in most populated EU cities. Nevertheless, urban air qual-

Correspondence to: A. Baklanov

(alb@dmi.dk) ity (UAQ) is still considered as a problem especially during short-term episodes that occur during adverse meteorological conditions, causing exceedances of short-term air quality standards (e.g. during episodes in 1995 in London $\mathrm{NO}_{2}$ exceeded $400 \mathrm{ppb}$ ). Short-term pollution episodes are presently one of the major concerns for the protection of human health in urban environment. This has lead to the introduction of EU Air Quality Directives to abate adverse health effects of air pollution to European citizens. The new EU air quality standards to be implemented by 2005 and 2010 will focus even more on episode prevention and forecasting. Moreover, a reliable urban scale forecast of air flows and meteorological fields is of primary support for urban emergency management systems for accidental toxic releases, fires, or even chemical, radioactive, or biological substance releases due to terrorist actions, the potential risk of which has been recently emerged.

The quality of the urban air pollution forecast and the Urban Air Quality Information and Forecasting Systems (UAQIFS) critically depends on the: (i) mapping of emissions, (ii) level of urban air pollution (UAP) models, and (iii) quality of meteorological fields in urban areas. The main problem in forecasting of UAP is the prediction of episodes with high pollutant concentration in urban areas. In these areas most of the well-known methods and models, based on in-situ meteorological measurements, fail to produce realistically the meteorological input fields for the UAP models. Many projects are aimed at developing UAP dispersion models and chemical transformation and at improving knowledge about pollutants and emissions. However, no significant efforts were put to improving forecasts of meteorological parameters in UAP models. These would be especially important in air pollution episodes (APEs) with low winds, stable stratification, local air circulations, topographic effects, breeze conditions, and internal boundary layers.

Published by Copernicus GmbH on behalf of the European Geosciences Union. 
Historically, UAP forecasting and numerical weather prediction (NWP) were developed separately. This was plausible in the previous decades when the resolution of NWP models was too low for city-scale air pollution forecasting. However, during the last decade substantial progress in NWP modelling and in the description of urban atmospheric processes was achieved. Modern nested NWP models utilise land-use databases down to hundred meters resolution or finer, and approach the necessary horizontal and vertical resolution to provide weather forecasts for the urban scale (see e.g. Baklanov et al., 2002). In combination with the recent scientific developments in the field of urban sublayer atmospheric physics (e.g. Martilli et al., 2002; Dupond et al., 2005a, b; Fisher et al., 2006) and the enhanced availability of high-resolution urban surface characteristics, the capability of NWP models to provide high quality urban meteorological data will, therefore, increase.

UAP models in operational UAQIFSs, as a rule, still use simple in-situ meteorological measurements which are fed into meteorological pre-processors (see Fig. 1 in Baklanov et al., 2005a). Lacking an adequate description of physical phenomena and the complex data assimilation and parameterisations of NWP models, these pre-processors do not achieve the potential of NWP models in providing all the meteorological fields needed by modern UAP models to improve the UAQ forecasts.

Despite the increased resolution of existing operational NWP models, urban and non-urban areas mostly contain similar sub-surface, surface, and boundary layer formulation. These do not account for specifically urban dynamics and energetics and their impact on the numerical simulation of the atmospheric boundary layer and its various characteristics (e.g. internal boundary layers, urban heat island, precipitation patterns). Additionally, NWP models are not primarily developed for air pollution modelling and their results need to be designed as input to urban and mesoscale air quality models.

Existing large scale pollution forecasting systems are already operating over domains that cover the European continent. Even if these systems do not have a spacial resolution sufficient to resolve the urban structure and meteorology, they provide the background to estimate boundary conditions and to evaluate the importance of large scale flow of pollutants over the target cities.

Urban populations spend typically over $80 \%$ of their time indoors at geographically varying locations during the day. The pollution they inhale indoors is filtered by the buildings and the ventilation systems. During the last decades increasing attention has been paid to these factors modifying the true exposure levels the populations experience. The ambient air quality, measured and modelled, is important for the ambient air quality management, but when the adverse health effects of the population are assessed, the time activity of population must be taken into account.
Therefore, due to the above mentioned reasons, the situation in UAQIFS is changing nowadays and requires a revision of the conventional conception of UAQ forecasting.

\section{Project objectives and realisation}

In response to the above mentioned research needs, the European Union research project called FUMAPEX: "Integrated Systems for Forecasting Urban Meteorology, Air Pollution and Population Exposure" was initiated within the COST 715 community (Fisher et al., 2006), and submitted to the Fifth Framework Programme, Subprogramme: Environment and Sustainable Development, Key Action 4: City of Tomorrow and Cultural Heritage. FUMAPEX started in November 2002 and will continue for a period of three years. FUMAPEX is a member of the CLEAR cluster of European Urban Air Quality Research (http://www.nilu.no/clear).

The main objectives of the FUMAPEX project are the following: (i) to improve meteorological forecasts for urban areas, (ii) to connect NWP models to UAP and population exposure (PE) models, (iii) to build improved UAQIFS, and (iv) to demonstrate their application in target cities located in various European climates. The FUMAPEX scheme of the improvements of meteorological forecasts in urban areas, interfaces and integration with UAP and PE models for the UAQIFS is presented in Fig. 1 of Baklanov et al. (2006a).

The improvement of urban meteorological forecasts will also provide information to city management regarding additional hazardous or stressing urban climate (e.g. urban runoff and flooding, icing and snow accumulation, high urban winds or gusts, heat or cold stress in growing cities and/or a warming climate). Moreover, the availability of reliable urban scale weather forecasts could be of relevant support for the emergency management of fires, accidental toxic emissions, potential terrorist actions, etc. (Baklanov et al., 2006b).

The improved forecast techniques can be used in two ways. Firstly, it can be the short-term episode forecasts for the next few days. Secondly, it is an integrated modelling system for long-term air quality management to predict future episodic pollution levels, taking into account estimated trends in local traffic and other emissions. In both ways the modelling system can be employed to evaluate alternative scenarios and to develop efficient strategies to reduce emissions, pollution levels, and PE to prevent health consequences in a cost-effective way.

In order to achieve the innovative project goal of establishing and implementing the improved UAQIFS to assist sustainable urban development, the following steps should be achieved:

1. improve predictions of the meteorological fields needed by UAP models by refining resolution and developing specific parameterisations of the urban effects in NWP models, 


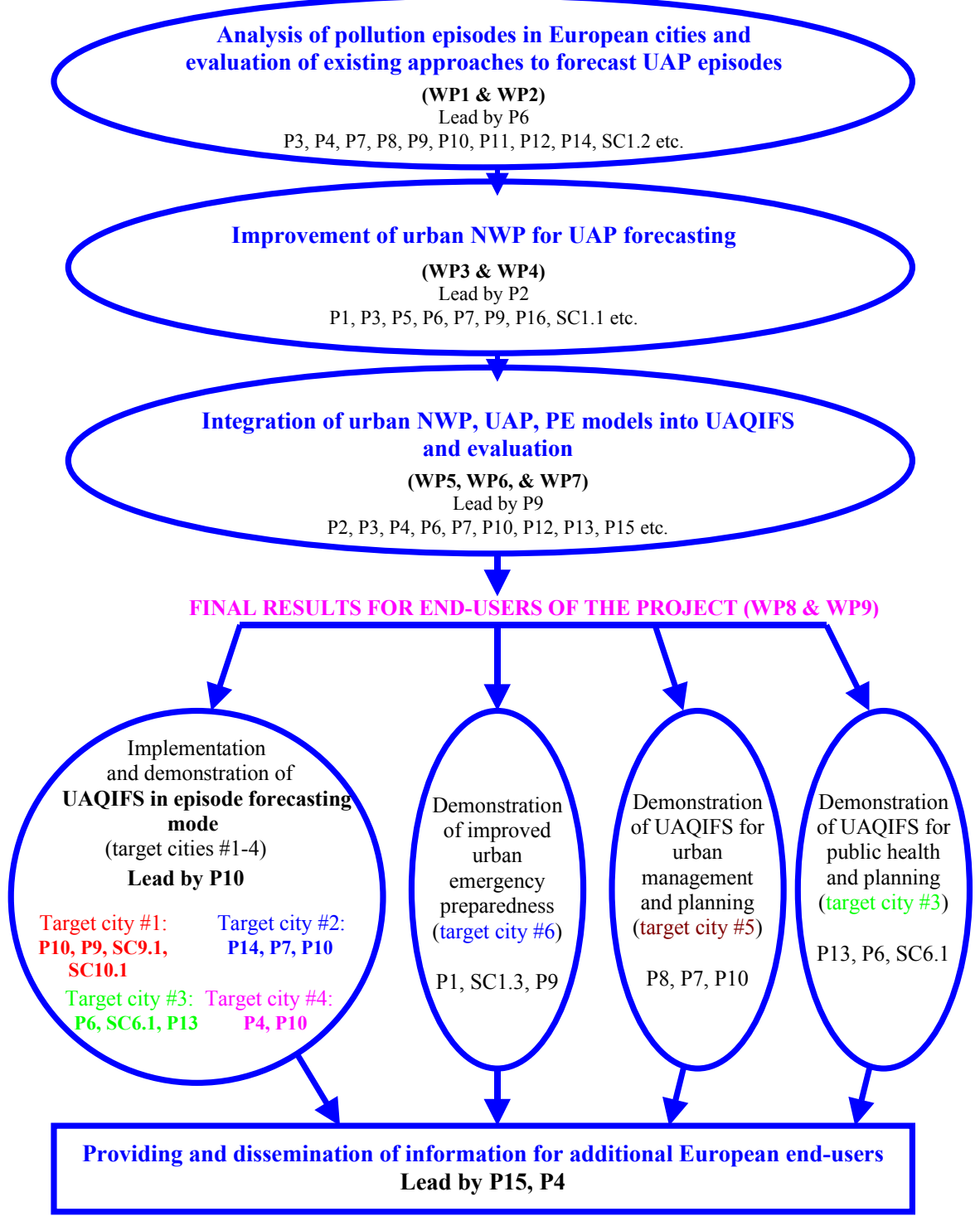

Fig. 1. FUMAPEX Work Packages, Participants, Subcontractors, their interconnection and horizontal organisation of the consortium, including several WP groups (NWP: Numerical Weather Prediction, UAP: Urban Air Pollution, PE: Population Exposure; Target cities: \#1 Oslo, \#2 - Turin, \#3 - Helsinki, \#4 - Valencia/Castellon, \#5 - Bologna, \#6 - Copenhagen).

2. develop suitable interface/meteorological preprocessors from NWP to UAP models,

3. validate the improvements in NWP models and meteorological pre-processors by evaluating their effects on UAP models against urban measurement data,

4. apply the improved meteorological data to UAQIFS, emergency preparedness and PE models, compare and analyse results, and

5. successfully link meteorologists/NWP modellers with UAP and public health scientists and "end-users" of UAQIFS.
The necessary steps are evolved in 10 separate, but interlinked Work Packages (WP, see below and Fig. 1) realised by 16 partners and 6 subcontractors (see the list of the participants in Table 1). They represent leading NWP centres, research institutions, organisations responsible for UAQ, PE forecast and control, and local/city authorities from 10 European countries. 
Table 1. The list of the FUMAPEX project participants and principal investigators (PIs).

\begin{tabular}{|c|c|c|c|c|}
\hline \multicolumn{5}{|c|}{ FUMAPEX Partners: } \\
\hline P1 & Danish Meteorological Institute (coordinator) & DMI & Denmark & $\begin{array}{l}\text { Dr. Alexander Baklanov } \\
\text { (project leader), } \\
\text { Mr. Alix Rasmussen }\end{array}$ \\
\hline $\mathrm{P} 2$ & German Weather Service & DWD & Germany & Mrs. Barbara Fay \\
\hline P5 & Ecole Centrale de Nantes - CNRS, Laboratory of Fluid Mechanics & ECN-CNRS & France & Dr. Patrice Mestayer \\
\hline P6 & Finnish Meteorological Institute & FMI & Finland & Prof. Jaakko Kukkonen \\
\hline P7 & ARIANET Consulting & ARIANET & Italy & Dr. Sandro Finardi \\
\hline P8 & Environmental Protection Agency of Emilia-Romagna Region & ARPA & Italy & Dr. Deserti Marco \\
\hline P9 & The Norwegian Meteorological Institute & DNMI & Norway & Dr. Norvald Bjergene \\
\hline P10 & Norwegian Institute for Air Research & NILU & Norway & Dr. Leiv Haavard Slordal \\
\hline $\mathrm{P} 15$ & Environment Institute - Joint Research Center & JRC EI & Italy & Dr. Andreas Skouloudis \\
\hline P16 & Swiss Federal Institute of Technology & EPFL/ETH & Schweiz & $\begin{array}{l}\text { Dr. Alain Clappier, } \\
\text { Dr. Mathias Rotach }\end{array}$ \\
\hline \multicolumn{5}{|c|}{ Subcontractors: } \\
\hline SC1.1 & Brockmann Consult/Uppsala University & $\mathrm{BC}$ & Sweden & Prof. Sergej Zilitinkevich \\
\hline $\mathrm{SC} 1.2$ & Université catolique de Louvain & UCL & Belgium & Prof. Guy Schayes \\
\hline SC1.3 & Danish Emergency Management Agency & DEMA & Denmark & Mr. Steen Hoe \\
\hline SC6.1 & Helsinki Metropolitan Area Council & YTV & Finland & Mr. Tarja Koskentalo \\
\hline SC9.1 & Norwegian Traffic Authorities & NTA & Norway & Mr. Pål Rosland \\
\hline SC10.1 & Municipality of Oslo & MO & Norway & Mrs. Gunhild Lutnaes \\
\hline
\end{tabular}

European Commission Scientific Officer: Dr. Viorel Vulturescu, DG Research

The WP structure (with leaders) is the following:

WP 1: Analysis and evaluation of APEs in European cities (J. Kukkonen, FMI)

WP 2: Assessment of different existing approaches to forecast UAP episodes (R. S. Sokhi, UH)

WP 3: Testing the quality of different operational meteorological forecasting systems for urban areas (B. Fay, DWD)

WP 4: Improvement of parameterisation of urban atmospheric processes and urban physiographic data classification (A. Baklanov, DMI)

WP 5: Development of interface between urban-scale NWP and UAP models (S. Finardi, Arianet)

WP 6: Evaluation of the suggested system (UAQIFS) to uncertainties of input data for UAP episodes (N. Bjergene, DNMI)

WP 7: Development and evaluation of PE models in combination with UAQIFS's (M. Jantunen, KTL)
WP 8: Implementation and demonstration of improved UAQIFS (L. H. Slørdal, NILU)

WP 9: Providing and dissemination of relevant information (A. Skouloudis, JRC)

WP 10: Project management and quality assurance (A. Rasmussen, DMI).

\subsection{Project realisation}

The project proceeds through the steps given below, each of which can be considered as a separate objective providing valuable results:

1. Classification of APEs in cities located in different European climatic and geographic regions (Fig. 2) focusing on relevant meteorological variables.

- Identification and classification of various types of APEs.

- Key pollutants relevant to EU Air Quality Directives and Daughter Directives (EC/96/62; EC/99/30) will be selected for different regions/city characteristics. 


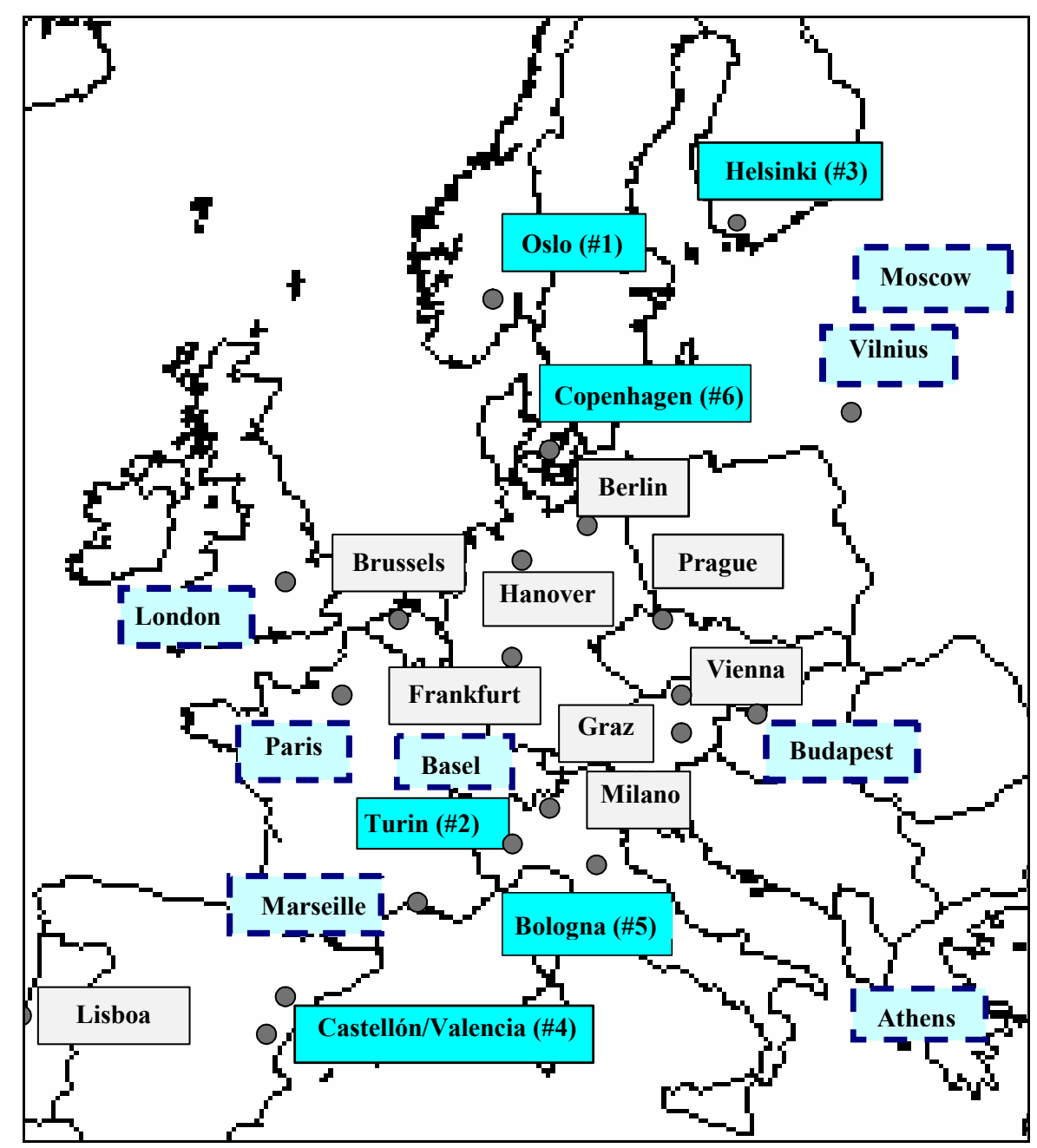

Fig. 2. Map of the selected European cities for air pollution episode analysis in FUMAPEX. The target cities for UAQIFS implementation are marked by a \# and blue background. Potential target cities for applying the FUMAPEX technique in future are marked with a dark-blue dashed border.

- Classification of meteorological conditions leading to pollution episodes and identification of the more relevant meteorological parameters to define these conditions.

- Compilation and analysis of existing datasets of concentration and meteorological data measured during pollution episodes.

2. Improvement of the quality of urban meteorological forecasting for UAP and PE models

- Improvement of urban weather forecasts and calculation of key meteorological parameters for pollution episodes (a hierarchy of NWP models from large scale Global Circulation Models to local-scale obstacle-resolving meteorological models will be employed).
- Improvement of boundary layer formulations/parameterisations and physiographic data description for urban areas.

- Development of assimilation techniques with satellite remote sensing data in NWP models.

- Development of interfaces to connect urban-scale NWP to UAP models.

3. Verification of the improved NWP, UAP, and PE models

- Evaluation of improved urban meteorological forecast models based on UAP episode.

- Estimation of sensitivity of UAP models to uncertainties in meteorological input data.

- Evaluation of impact of the improved output of UAQ models on simulations of an urban PE model. 
4. Application of UAQIFS and emergency systems.

- Integration of the improved NWP, UAP and PE models into UAQIFSs.

- Implementation of the new improved UAQIFS in the (i) air quality forecasting mode to be applied in four target cities, (ii) urban management or public health and planning mode in one selected target city, and (iii) the improved emergency preparedness system in one selected target city.

The six target city candidates for the improved UAQIFS and emergency systems implementations and corresponding "end-users" are the following (Fig. 2):

$\begin{array}{ll}\text { \#1 - Oslo } & \Rightarrow \text { Municipality of Oslo, } \\ \text { (Norway) } & \text { Norwegian Traffic Authorities; } \\ \text { \#2-Turin } & \Rightarrow \text { Environmental Protection } \\ \text { (Italy) } & \text { Agency of Piedmont; } \\ \text { \#3- Helsinki } & \Rightarrow \text { Helsinki Metropolitan } \\ \text { (Finland) } & \text { Area Council; } \\ \text { \#4-Castellon/Valencia } & \Rightarrow \text { Centro De Estudios Ambien- } \\ \text { (Spain) } & \text { tales Del Mediterrano; } \\ \text { \#5- Bologna } & \Rightarrow \text { Environmental Protection } \\ \text { (Italy) } & \text { Agency of Emilia-Romagna; } \\ \text { \#6-Copenhagen } & \Rightarrow \text { Danish Emergency } \\ \text { (Denmark) } & \text { Management Agency. }\end{array}$

\section{Project scientific achievements}

In order to resolve the above-discussed issues and FUMAPEX objectives, at the current stage of the project (after the first two years) the following innovative studies were realised for UAQIFSs:

1. The database of meteorological and chemical measurement data for UAP episodes in European cities was established and key meteorological parameters for those episodes/climatological regions identified and classified (Valkama et al., 2004; Kukkonen et al., 2005). These can also serve for future NWP/UAP model development and validation.

2. The assessment and intercomparison of the present simple and complex meteorological pre-processors to UAP models was provided (Slördal et al., 2005; Sokhi et al., 2003; Batchvarova et al., 2003). The attention was focused on characterisation of the urban boundary layer and to aspects more relevant to the "end-users" needs.

3. Project leads to the investigation and improvement of different European operational NWP models in urban environment and a validation of these modified models on urban measurements for selected European cities and typical high pollution episodes (Baklanov et al., 2005a). The study of performance of NWP models with higher resolution was performed for urban areas (Fay et al., 2005; Neunhäuserer et al., 2004).

4. Three variants of the NWP model 'urbanisation' were suggested; improved parameterisations of the urban boundary layer in NWP models were established and validated (Baklanov et al., 2005a; Hamdi and Shayes, 2005), consisting of improved urban temperature and heat flux parameterisations and their effects on winds, turbulence, stability, and mixing height.

5. The important urban soil and surface parameterisations (Mestayer and Bottema, 2002) improved by providing and validating state-of-the-art soil and roughness models for urban areas (Dupont et al., 2005 ${ }^{1}$; Martilli et al., 2002; Baklanov et al., 2005a; Mahura et al., 2005) and scale-dependent input parameters for the obstacle resolving UAPs were realised due to the new European regulations.

6. Improved theory and parameterisation of turbulence and mixing height, with a focus on the relevant stable boundary layer, are suggested and tested for urban NWP/UAP models (Zilitinkevich et al., 2002, 2005; Zilitinkevich and Baklanov, 2002; Zilitinkevich and Esau, 2004; Baklanov, 2002; Finardi et al., 2005).

7. The extended data assimilation of surface characteristics into the urban scale NWP models can add crucial data and, thus, improve the models. High resolution satellite data (e.g. remotely sensed snow cover and heat fluxes in urban areas) were accommodated, and assimilation algorithms were developed and tested for urban areas (Kitwiroon et al., 2002; Eastwood et al., 2004).

8. Project also provided improved model interfaces/meteorological pre-processors, capable of connecting mesoscale meteorological model results to updated UAP and atmospheric chemistry models, which incorporated the above improvements in resolution, data assimilation, and parameterisation (Finardi et al., 2005).

9. The sensitivity study on the relevance of the above modifications in NWP models and meteorological preprocessors on the detailed description of local circulation and urban meteorology was established and validated with meteorological measurements for APEs in European cities (Fay et al., 2005; Baklanov et al., 2005a; Neunhäuserer and Fay, 2005).

10. The sensitivity study on the relevance of the above modifications on the performance of UAP models in UAQIFS was realised and validated with measurements

\footnotetext{
${ }^{1}$ Dupont, S., Mestayer, P. G., Guilloteau, E., Berthier, E., and Andrieu, H.: Parameterisation of the Urban Water Budget with the Sub-Meso Soil Model, J. Appl. Meteorol., submitted, 2005.
} 
of APEs in European cities (Ødegaard et al., 2005; Palau et al., 2005).

11. Improved urban meteorology and air pollution modelling systems suitable to be applied to any European urban area on the basis of available operational NWP models were established (Slördal, 2004). These new UAQIFSs are implementing in the 6 European target cities mentioned in Sect. 2 and demonstrating with the direct participation of local authorities and other 'endusers'. In addition to the six target cities there have also been some tests of improved UAQIFS models for London (conducted by UH) and Paris (conducted by CORIA).

12. Linking ambient air pollution models with population time-activity to assess the true exposure levels caused by the ambient pollution was realised (Hänninen, 2005; Jantunen et al., 2004, 2005) and the new generation UAQIFS, integrated from urban meteorology to air quality and population exposure, was built and tested for some target cities, e.g. Helsinki (Jantunen et al., 2004, 2005; Hänninen et al., 2005a, b; Baklanov et al., 2006a).

One example of the FUMAPEX strategy tests for the London metropolitan area (Sokhi et al., 2005: see Chapter 2 in the final FUMAPEX report: Baklanov, 2005, vol. 2) is demonstrated in Fig. 3. The improved city-scale meteorological model MM5 integrated with the urban air pollution modelling system (central columns), in comparison with the original non-urban version (right columns), shows substational improvement of the air quality forecast for urban areas: differences between predicted and observed values can be reduced (by up to a factor of three) by using the high resolution urban land cover characteristics.

The FUMAPEX project was focused, first of all, on the prediction of episodes; however, we also considered possible applications of the system for environmental impact assessments and long-term predictions. In the latest paper of this issue: "Integrated systems for forecasting urban meteorology, air pollution and population exposure" (Baklanov et al., 2006a) these aspects were also considered. In particular, the Urban Air Quality Information and Forecasting Systems were realised in the target city of Bologna (Italy) for the urban management and planning mode, in Helsinki (Finland) for the public health assessment mode.

This paper is an overview introducing and relating the other FUMAPEX papers of the special issue. Some of the above mentioned results and achievements of the FUMAPEX project are presented in the papers of this special issue, other are published in different papers and reports shown in Sect. 4.

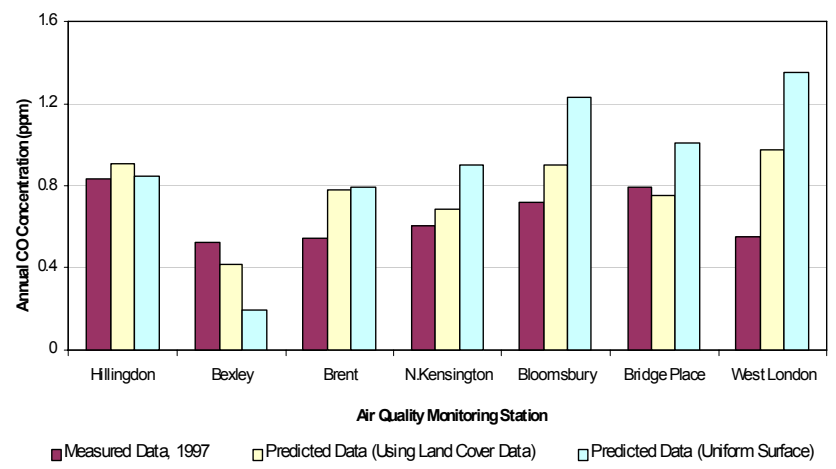

Fig. 3. Comparison of predicted annual CO concentrations (ppm), using the original non-urban version (right columns) and improved city-scale MM5 model integrated with the urban air pollution modelling system (central columns), in comparison with measured values (left columns) from seven monitoring stations in London (Sokhi et al., 2005).

\subsection{Project expected impacts}

The main impact of the FUMAPEX project will be the improved, validated, inter-compared, and accessible UAQIFS implemented in an increasing number of European cities. Forecast and prevention of the worst air pollution episodes in large cities according to air quality directives will lead to an improved quality of human life and environment.

Additional impacts are the potential use of improved weather and pollution forecasts for emergency management (fires, accidental emissions, terror actions, etc.) and for long-term air quality management (scenario studies, emission abatement strategies, sustainable city life, etc.). Linking scientists and administrators of different background, disciplines, and specialisation will also lead to speeding-up and innovation in related urban research and application (e.g. urban climate, sustainable transport, environment, health, etc.) addressed by the EC framework program.

\section{FUMAPEX publications}

The complete list of FUMAPEX publications (including conference proceedings and presentations) as well as the below mentioned reports are available on the project web-site: http://fumapex.dmi.dk/Index/index_docu.html. They can be downloaded, using the address: http://fumapex.dmi.dk/Pub/ Docu/Reports/XXX.pdf, where XXX.pdf are the report addresses mentioned in the below reference list. 


\section{Scientific papers}

\section{References}

Baklanov, A.: The mixing height in urban areas - a review, in: Mixing height and inversions in urban areas, COST Action 715, Office for Official Publications of the European Communities, EUR 20451, pp. 9-28, 2002.

Baklanov, A.: European FUMAPEX project: Integrated Systems for Forecasting Urban Meteorology, Air Pollution and Population Exposure, EURASAP Newsletter, March 2004, 52, 6-36, 2004.

Baklanov, A. and Kuchin, A.: The mixing height in urban areas: comparative study for Copenhagen, Atmos. Chem. Phys. Discuss., 4, 2839-2866, 2004.

Baklanov, A., Rasmussen, A., Fay, B., Berge, E., and Finardi, S.: Potential and Shortcomings of Numerical Weather Prediction Models in Providing Meteorological Data for Urban Air Pollution Forecasting, Water, Air and Soil Poll., Focus, 2(5-6), 43-60, 2002.

Baklanov, A., Gross, A., and Sørensen, J. H.: Modelling and forecasting of regional and urban air quality and microclimate, J. Comput. Technol., 9, 82-97, 2004.

Baklanov, A., Hänninen, O., Slørdal, L. H., Kukkonen, J., Bjergene, N., Fay, B., Finardi, S., Hoe, S. C., Jantunen, M., Karppinen, A., Rasmussen, A., Skouloudis, A., Sokhi, R. S., and Sørensen, J. H.: Integrated systems for forecasting urban meteorology, air pollution and population exposure, Atmos. Chem. Phys. Discuss., 6, 1867-1913, 2006a.

Baklanov, A., Sørensen, J. H., Hoe, S., and Amstrup, B.: Urban Meteorological Modelling for Nuclear Emergency Preparedness, J. Environ. Radioactivity, doi:10.1016/j.jenvrad.2005.01.018, 85, 154-170, 2006b.

Baklanov, A., Mestayer, P., Clappier, A., Zilitinkevich, S., Joffre, S., and Mahura, A.: On parameterizations of urban atmosphere sublayer in meteorological models, Atmos. Chem. Phys. Discuss., 5, 12 119-12 176, 2005a.

Bruinen de Bruin, Y., Hänninen, O., Carrer, P., Maroni, M., Kephalopoulos, S., Scotto di Marco, G., and Jantunen, M.: Simulation of working population exposures to carbon monoxide using EXPOLIS-Milan microenvironment concentration and time activity data, J. Expo. Anal. Environ. Epidemiol., 14(2), 154163, 2004.

Calori, G., Clemente, M., De Maria, R., Finardi, S., Lollobrigida, F., and Tinarelli, G.: Air quality integrated modelling in Turin urban area, Environmental Modelling and Software, as part of the Urban Air Quality 2003 Special Issue, 2003.

Chenevez, J., Baklanov, A., and Sørensen, J. H.: Pollutant Transport Schemes Integrated in a Numerical Weather Prediction Model: Model description and Verification Results, Meteorological Applications, 11(3), 265-275, 2004.

Fay, B. and Neunhäuserer, L.: Evaluation of very high-resolution simulations with the non-hydrostatic numerical weather prediction model Lokalmodell for urban air pollution episodes in Helsinki, Oslo and Valencia, Atmos. Chem. Phys. Discuss., 5, 8233-8284, 2005.

Fisher, B., Kukkonen, J., Piringer, M., Rotach, M., and Schatzmann, M.: Meteorology applied to urban air pollution problems: concepts from COST 715, Atmos. Chem. Phys. Discuss., 6, 555$564,2006$.
Gross, A. and Baklanov, A.: Modelling the influence of dimethyl sulphide on the aerosol production in the marine boundary layer, Int. J. Environ. Poll., 22, 51-71, 2004.

Hamdi, R. and Schayes, G.: Validation of the Martilli's Urban Boundary Layer Scheme with measurements from two midlatitude European cities, Atmos. Chem. Phys. Discuss., 5, 42574289, 2005.

Hänninen, O., Kruize, H., Lebret, E., and Jantunen, M.: EXPOLIS simulation model: $\mathrm{PM}_{2.5}$ application and comparison with measurements in Helsinki, J. Expo. Anal. Environ. Epidemiol., 13(1), 74-85, 2003.

Hänninen, O., Koistinen, K., Rotko, T., Bruinen de Bruin, Y., and Jantunen, M.: Altistusmalleilla turvallista kaupunki-ilmaa? (Exposure models as a tool to provide clean air to urban populations) Ilmansuojelu-uutiset (Finnish air pollution prevention news, in Finnish), 2/2004, pp. 35-42, 2004.

Hänninen, O. O., Lebret, E., Ilacqua, V., Katsouyanni, K., Künzli, N., Srám, R. J., and Jantunen, M.: Infiltration of ambient $\mathrm{PM}_{2.5}$ and levels of indoor generated non-ETS $\mathrm{PM}_{2.5}$ in residences of four European cities, Atmos. Environ., 38(37), 6411-6423, 2004.

Hänninen, O. O., Lebret, E., Tuomisto, J. T., and Jantunen, M.: Characterization of Model Error in the Simulation of $\mathrm{PM}_{2.5}$ Exposure Distributions of the Working Age Population in Helsinki, Finland, J. Air Waste Manage. Assoc., 55, 446-457, 2005a.

Hänninen, O. O., Palonen, J., Tuomisto, J., Yli-Tuomi, T., Seppanen, O., and Jantunen, M. J.: Reduction potential of urban PM2.5 mortality risk using modern ventilation systems in buildings, Indoor Air, 15(4), 246, 2005b.

Hänninen, O., Kruize, H., Lebret, E., and Jantunen, M.: EXPOLIS simulation model, PM2.5 application and comparison with measurements in Helsinki, J. Expo. Anal. Environ. Epidemiol., 13(1), 74-85, 2003.

Hänninen, O. O. and Jantunen, M. J.: Simulation of PM2.5 home indoor concentrations in Helsinki, Epidemiology, 13(4), 881, 2002.

Hasager, C. B., Nielsen, N. W., Boegh, E., Jensen, N. O., Christensen, J. H, Dellwik, E., and Soegaard, H.: Effective roughnesses calculated from satellite-derived land cover maps and hedge information and used in a weather forecasting model, Boundary-Layer Meteorol., 109, 227-254, 2003.

Kitwiroon, N., Sokhi, R. S., Luhana, L., and Teeuw, R. M.: Improvements in air quality modeling by using surface boundary layer parameters derived from satellite land cover data, Water, Air and Soil Poll., Focus, 2, 29-41, 2002.

Kukkonen, J., Pohjola, M., Sokhi, R., Luhana, L., Kitwiroon, N., Fragkou, L., Rantamäki, M., Berge, E., Odegaard, V., Slørdal, L. H., Denby, B., and Finardi, S.: Analysis and evaluation of local-scale PM10 air pollution episodes in four European cities: Helsinki, London, Milan and Oslo, Special issue: Fourth International Conference on Urban Air Quality: Measurement, Modelling and Management, 25-28 March 2003, edited by: Sokhi, R., Atmos. Environ., 39/15, 2759-2773, 2005.

Kukkonen, J., Partanen, L., Karppinen, A., Ruuskanen, J., Junninen, H., Kolehmainen, M., Niska, H., Dorling, S., Chatterton, T., Foxall, R., and Cawley, G.: Extensive evaluation of neural network models for the prediction of $\mathrm{NO} 2$ and PM10 concentrations, compared with a deterministic modelling system and measurements in central Helsinki, Atmos. Environ., 37(32), 45394550, 2003. 
Mahura, A., Leroyer, S., Mestayer, P., Calmet, I., Dupont, S., Long, N., Baklanov, A., Petersen, C., Sattler, K., and Nielsen, N. W.: Large Eddy Simulation of Urban Features for Copenhagen Metropolitan Area, Atmos. Chem. Phys. Discuss., 5, 11183 $11213,2005$.

Martilli, A., Clappier, A., and Rotach, M. W.: An urban surfaces exchange parameterisation for mesoscale models, Boundary Layer Meteorol., 104, 261-304, 2002.

Mestayer, P., Almbauer, R., and Tchepel, O.: Urban Field Campaigns, Air quality in cities, edited by: Moussiopoulos, N., Springer Verlag Berlin Heidelberg, pp. 51-89, 2003.

Mestayer, P. and Bottema, M.: Parameterisation for roughness parameters in urban areas, in: COST Action 715 Workshop on Urban Boundary Layer Parameterisations (Zurich, 24-25 May 2001), edited by: Rotach, M., Fisher, B., and Piringer, M., Office for Official Publications of the European Communities, EUR 20355, pp. 51-61, 2002.

Mestayer, P. G., Durand, P., Augustin, P., Bastin, S., Bonnefond, J.-M., Bénech, B., Campistron, B., Coppalle, A., Delbarre, H., Dousset, B., Drobinski, P., Druilhet, A., Fréjafon, E., Grimmond, S., Groleau, D., Irvine, M., Kergomard, C., Kermadi, S., Lagouarde, J.-P., Lemonsu, A., Lohou, F., Long, N., Masson, V., Moppert, C., Noilhan, J., Offerle, B., Oke, T., Pigeon, G., Puygrenier, V., Roberts, S., Rosant, J.-M., Saïd, F., Salmond, J., Talbaut, M., and Voogt, J.: The Urban Boundary Layer Field Experiment over Marseille. UBL/CLU-ESCOMPTE: Experimental Set-up and First Results, Boundary-Layer Meteorol., 114, 315365, 2005.

Neunhäuserer, L., Fay, B., Baklanov, A., Bjergene, N., Kukkonen, J., Ødegaard, V., Palau, J. L., Pérez Landa, G., Rantamäki, M., Rasmussen, A., and Valkama, I.: Evaluation and comparison of operational NWP and mesoscale meteorological models for forecasting urban air pollution episodes - Helsinki case study, in: 9th International Conference on Harmonisation within Atmospheric Dispersion Modelling for Regulatory Purposes, edited by: Suppan, P., 1-4 June 2004, Garmisch-Partenkirchen, Germany, Vol. 2. pp. 245-249, 2004.

Niemi, J. V., Tervahattu, H., Vehkamäki, H., Kulmala, M., Koskentalo, T., Sillanpää, M., and Rantamäki, M.: Characterization and source identification of a fine particle episode in Finland, Atmos. Environ., 38(30), 5003-5012, 2004.

Palau, J. L., Pérez-Landa, G., Diéguez, J. J., Monter, C., and Millán, M. M.: The importance of meteorological scales to forecast air pollution scenarios on a complex-terrain coastal site of the Iberian Peninsula, Atmos. Chem. Phys., 5, 2771-2785, 2005.

Palau, J. L., Perez-Landa, G., Melia, J., Segarra, D., and Millan, M. M.: A study of the dispersion of a power plant on complex terrain under winter conditions using high-resolution mesoscale and Lagrangian particle models, Atmos. Chem. Phys., 6, 11051134,2006

Pohjola, M. A., Rantamäki, M., Kukkonen, J., Karppinen, A., and Berge, E.: Meteorological evaluation of an Air Pollution Episode in Helsinki in December 1995, Ilmansuojelu (Magazine of the Finnish Air Pollution Prevention Society), 3/2004, pp. 8-14, 2004.

Pohjola, M. A., Kukkonen, J., Rantamäki, M., Karppinen, A., and Berge, E.: Meteorological evaluation of a severe air pollution episode in Helsinki on 27-29 December, 1995, Boreal Environ. Res., 9, 75-87, 2004.
Rantamäki, M., Pohjola, M. A., Tisler, P., Bremer, P., Kukkonen, J., and Karppinen, A.: Evaluation of two versions of the HIRLAM numerical weather prediction model during an air pollution episode in southern Finland, Special issue: Fourth International Conference on Urban Air Quality: Measurement, Modelling and Management, 25-28 March 2003, edited by: Sokhi, R., Atmos. Environ., 39/15, 2775-2786, 2005.

Schatzmann, M. , Bächlin, W., Emeis, S., Kühlwein, J., Leitl, B., Müller, W. J., Schäfer, K., and Schlünzen, H.: Development and validation of tools for the implementation of European air quality policy in Germany (Project VALIUM), Atmos. Chem. Phys. Discuss., 5, 9621-9639, 2005.

Slørdal, L. H., Finardi, S., Batchvarova, E., Sokhi, R. S., Fragkou, E., and D'Allura, A.: Limitations of air pollution episodes forecast due to boundary-layer parameterisations implemented in mesoscale meteorological models, Air Pollution Modelling and its Application, NATO ITM, October 25-29, 2004, Banff, Canada, 2004.

Zilitinkevich, S. S. and Esau, I. N.: The effect of baroclinicity on the depth of neutral and stable planetary boundary layers, Quart. J. Roy. Met. Soc., 129, 3339-3356, 2004.

Zilitinkevich, S. S., Hunt, J. C. R., Grachev, A. A., Esau, I. N., Lalas, D. P., Akylas, E., Tombrou, M., Fairall, C. W., Fernando, H. J. S., Baklanov, A., and Joffre, S. M.: The effect of large eddies on the convective heat/mass transfer over complex terrain: advanced theory and its validation against experimental and LES data, Croatian Meteorological Journal, 40, 20-26, 2005.

Zilitinkevich, S. S., Esau, I. N., and Baklanov, A.: Atmospheric boundary layers in storms: advanced theory and modelling applications, Adv. Geosci., 2, 47-49, 2005.

Zilitinkevich, S. and Baklanov, A.: Calculation of the height of stable boundary layers in practical applications, Boundary-Layer Meteorol., 105(3), 389-409, 2002.

Zilitinkevich, S., Baklanov, A., Rost, J., Smedman, A.-S., Lykosov, V., and Calanca, P.: Diagnostic and prognostic equations for the depth of the stably stratified Ekman boundary layer, Q. J. Roy. Meteorol. Soc., 128, 25-46, 2002.

\section{FUMAPEX Reports and PhD Theses}

\section{References}

Baklanov, A. (Ed.): FUMAPEX Final Project Scientific Report, in 3 volumes, URL: FUMAPEX-FSR-vol1.fv.pdf; FUMAPEX-FSR-vol2.fv.pdf; FUMAPEX-FSR-vol3.fv.pdf, 2005.

Baklanov, A.: FUMAPEX: Integrated Systems for Forecasting Urban Meteorology, Air Pollution and Population Exposure. D9.2: Second Annual Report for Dissemination, March 2005, DMI, Copenhagen, Denmark, 71 p., URL: FUMAPEX_D9.2. DissReport.fv.pdf, 2005.

Baklanov, A. (Ed.): Integrated and validated NWP systems incorporating urban improvements, FUMAPEX M4.4 Report, Danish Meteorological Institute, Copenhagen, Denmark, 136 p., URL: FUMAPEX_M4.4.fv.pdf, 2005.

Baklanov, A. and Joffre, S. (Eds.): Improved Models for Computing the Roughness Parameters of Urban Areas, Baklanov, A., Mestayer, P., Schatzmann, M., Zilitinkevich, S., Clappier, A., et 
al. (co-authors), D4.4 FUMAPEX Report, November 2003, DMI Sci. Report 03-19, ISBN: 87-7478-495-1, 51 p., URL: DMI Scientific Report No. 03-19, 2003.

Baklanov, A. and Mestayer, P. (Eds.): Improved parameterisations of urban atmospheric sublayer and urban physiographic data classification, Baklanov, A., Batchvarova, E., Calmet, I., Clappier, A., Chordá, J. V., Diéguez, J. J., Dupont, S., Fay, B., Fragkou, E., Hamdi, R., Kitwiroon, N., Leroyer, S., Long, N., Mahura, A., Mestayer, P., Nielsen, N. W., Palau, J. L., PérezLanda, G., Penelon, T., Rantamäki, M., Schayes, G., and Sokhi, R. S. (co-authors), D4.1, 4.2 and 4.5 FUMAPEX Report, April 2004, Copenhagen, DMI, Denmark, DMI Scientific Report: \#0405, ISBN 87-7478-506-0, URL: FUMAPEX_D4.1-2-5.fv.pdf, 2004.

Baklanov, A. and Zilitinkevich, S. (Eds.): Parameterisation of nocturnal UBL for NWP and UAQ models. D4.6 FUMAPEX Report, Danish Meteorological Institute, Copenhagen, Denmark. 70 p., URL: FUMAPEX_D4.6.fv.pdf, 2004.

Baklanov, A. (Ed.): FUMAPEX Integrated Systems for Forecasting Urban Meteorology, Air Pollution and Population Exposure - Project Kick-off Meeting and First Progress Report, DMI Sci. Report 03-12, ISSN 0905-3263, April 2003, 140 p., URL: http:// glwww.dmi.dk/f+u/publikation/vidrap/2003/Sr03-12.pdf, 2003.

Baklanov, A.: Integrated Systems for Forecasting Urban Meteorology, Air Pollution and Population Exposure, FUMAPEX (EVK4-CT-2002-00097) 5FP project, D9.1: First annual report for dissemination, February, 18 p., URL: FUMAPEX_D9. 1.DissReport.fv.pdf, 2004.

Batchvarova, E., Sokhi, R., Palau, J. L., et al.: "Comparison and analysis of currently employed meteorological approaches for modelling urban air pollutants" and "Identification of gaps in met data required by UAP models for characterising urban BL", FUMAPEX D2.3-2.4 Report, December, 2003.

Eastwood, S., Ødegaard, V., and Midtb $\varnothing$, K. H.: Algorithms for assimilation of snow cover, D4.3 FUMAPEX Report, September 2004, Norwegian Meteorological Institute, Oslo, Norway, 21 p., URL: FUMAPEX_D4.3.fv.pdf, 2004.

Fay, B.: Overview of NPW/wind field models in FUMAPEX, D3.1 report for FUMAPEX, 29 p., 2003a.

Fay, B.: Design of model comparison study, D3.2 report for FUMAPEX, 26 p., 2003b.

Fay, B., Neunhäuserer, L., Pérez-Landa, G., Palau, J. L., Dieguez, J. J., Ødegaard, V., Bjergene, N., Sofiev, M., Rantamäki, M., Valkama, I., Kukkonen, J., Rasmussen, A., and Baklanov, A.: Model simulations and preliminary analysis for three air pollution episodes in Helsinki, D3.3 FUMAPEX Report, DWD, Germany, URL: FUMAPEX_D3.3.fv.pdf, 2004.

Fay, B., Neunhäuserer, L., Palau, J. L., Pérez-Landa, G., Dieguez, J. J., Ødegaard, V., Bonafé, G., Jongen, S., Rasmussen, A., Amstrup, B., Baklanov, A., Damrath, U.: Evaluation and intercomparison of operational mesoscale models for FUMAPEX target cities, FUMAPEX Report for D3.4, DWD Offenbach, Germany, 110 p., URL: FUMAPEX_D3.4_fv.pdf, 2005.

Finardi, S. (Ed.): Definition of NWP models output products, UAP models input needs and gaps to be filled, FUMAPEX report for M5.1, Arianet, Italy, 2003.

Finardi, S. (Ed.), Baklanov, A., Clappier, A., Fay, B., Joffre, S., Karppinen, A., Ødegaard, V., Slordal, L. H., Sofiev, M., Sokhi, R. S., and Stein, A.: Improved interfaces and meteorological pre- processors for urban air pollution models, Deliverable 5.2-3 of the EC FUMAPEX project, Arianet, Milan, Italy, 97 p., URL: FUMAPEX_D5.2-3.fv.pdf, 2005.

Finardi, S. (Ed.), Baklanov, A., Batchvarova, E., Clappier, A., Fay, B., Joffre, S., Karppinen, A., Slordal, L. H., Sokhi, R. S., Kitwiroon, N., and Stein, A.: Guidelines for the construction of the interfaces from operational NWP models to different types of UAP models, D5.1 FUMAPEX Report, Arianet, Italy, URL: FUMAPEX_D5.1.fv.pdf, 2004.

Hänninen, O. and Jantunen, M.: Refined and validated population exposure models, FUMAPEX report for D7.1, KTL, 25 p., 2003.

Hänninen, O., Karppinen, A., Valkama, I., Kousa, A., Koskentalo, T., and Jantunen, M.: Integration of population exposure models to the urban air quality information and forecasting system in Helsinki, FUMAPEX project report deliverable D7.3, URL: FUMAPEX_D7.3.fv.pdf, 2004.

Hänninen, O. O.: Probabilistic and deterministic time-locationactivity models for urban populations, D7.2 FUMAPEX Report, KTL, Finland, URL: FUMAPEX_D7.2.fv.pdf, 2004.

Hänninen, O. O., Karppinen, A., Valkama, I., Kousa, A., Kukkonen, J., and Jantunen, M.: Refined and validated population exposure models, FUMAPEX project report deliverable D7.1, URL: FUMAPEX_D7.1.fv.pdf, 2003.

Hänninen, O.: Probabilistic Modelling of PM2.5 Exposures in the Working Age Population of Helsinki Metropolitan Area, Publications of the National Public Health Institute (KTL) A10/2005, PhD dissertation, 2005.

Hamdi, R. and Schayes, G.: Improving the Martilli's urban boundary layer scheme: off-line validation over different urban surfaces, FUMAPEX WP4 report, UCL contribution, UCL, Louvain-La-Neuve, Belgium, URL: FUMAPEX_D4.5.UCL_ Report.pdf, 2004.

Hamdi, R.: On the study of the atmospheric boundary layer over urban areas with the urbanized version of TVM. Universite catolique de Louvain, Belgium, PhD dissertation, 2005.

Long, N.: Présentation et procédure d'utilisation de DFMap, LMF internal report, September, 2002.

Long, N.: Analyses morphologiques et aérodynamiques du tissu urbain: application à la micro climatologie de Marseille pendant la campagne Escompte, Thèse de Doctorat en Dynamique des Milieux Naturels et Anthropisés Passés et Actuels de l'USTLille, 5 décembre, 2003.

Mestayer, P., Dupont, S., Calmet, I., Leroyer, S., Mahura, A., and Penelon, T.: SM2-U: Soil Model for Sub-Meso scales Urbanized version, Model Description, Deliverable D4.2 for FUMAPEX WP4, Project report, Spring 2004, Nantes, ECN, France, URL: FUMAPEX_D4.2.SM2U_descr.pdf, 2004.

Millan, M. (Ed.): Ozone dynamics in the Mediterranean basin. Air pollution research report 78, EC DG RTD-CEAM, 287 p., 2003.

Ødegård, V.: Guidelines to the study of sensitivity of UAP forecasts to meteorological input, FUMAPEX Deliverable D6.1 Report, Met.no, May, URL: FUMAPEX_D6.1.fv.pdf, 2004.

Ødegård, V. (Ed.), D’Allura, A., Baklanov, A., Diéguez, J. J., Fay, B., Finardi, S., Glaab, H., Hoe, S. C., Millán, M., Mahura, A., Neunhäuserer, L., Palau, J. L., Perez, G., Slørdal, L. H., Stein, A., and Sørensen, J. H.: Study of the sensitivity of UAP forecasts to meteorological input, FUMAPEX Report for D6.2, Oslo, Met.no, 101 p., URL: FUMAPEX_D6.2_fv.pdf, 2005. 
Roulet, Y.-A.: Validation and application of an urban turbulence parameterisation scheme for mesoscale atmospheric models, Thèse de l'EPFL no. 3032, 2004.

Slördal, L. H. (Ed.): FUMAPEX: Guidelines of output from UAQIFSs as specified by end-users, FUMAPEX D8.1 report, NILU Report OR 2/2004, Ref: U-102144, 2004.

Sokhi, R. S., Kitwiroon, N., and Luhana, L.: FUMAPEX Datasets of Urban Air Pollution Models and Meteorological Preprocessors, D2.1-2.2 report for FUMAPEX, 41 p., 2003.

Valkama, I. and Kukkonen, J.: Identification and classification of air pollution episodes in terms of pollutants, concentration levels and meteorological conditions, FUMAPEX Deliverable D1.2, October, 2003.
Valkama, I. (Ed.): Identification and evaluation of the practical measures taken during episodes, in the selected European cities, Valkama, I., Bonafe, G., Coppalle, A., Deserti, M., Kitwiroon, N., Koskentalo, T., Kousa, Lollobrigida, F., Luhana, L., De Maria, R., Cascone, C., Palau, J. L., Rosland, P., Slørdal, L. H., and Sokhi, R. S. (co-authors): FUMAPEX Deliverable D1.3 Report, 26 April, URL: FUMAPEX_D1.3.fv.pdf, 2004.

Valkama, I. and Kukkonen, J.: Identification and classification of air pollution episodes in terms of pollutants, concentration levels and meteorological conditions, FUMAPEX Deliverable D1.2, 24 October, URL: FUMAPEX_D1.2.fv.pdf, 2003. 